\title{
Effectiveness of strategies for solving everyday problems during early and later adulthood: A reexamination of the Everyday Problem Solving Inventory
}

Joseph P. McFall

West Virginia University

Follow this and additional works at: https://researchrepository.wvu.edu/etd

\section{Recommended Citation}

McFall, Joseph P., "Effectiveness of strategies for solving everyday problems during early and later adulthood: A reexamination of the Everyday Problem Solving Inventory" (2010). Graduate Theses, Dissertations, and Problem Reports. 4631.

https://researchrepository.wvu.edu/etd/4631

This Dissertation is protected by copyright and/or related rights. It has been brought to you by the The Research Repository @ WVU with permission from the rights-holder(s). You are free to use this Dissertation in any way that is permitted by the copyright and related rights legislation that applies to your use. For other uses you must obtain permission from the rights-holder(s) directly, unless additional rights are indicated by a Creative Commons license in the record and/ or on the work itself. This Dissertation has been accepted for inclusion in WVU Graduate Theses, Dissertations, and Problem Reports collection by an authorized administrator of The Research Repository @ WVU.

For more information, please contact researchrepository@mail.wvu.edu. 


\section{Joseph P. McFall}

\section{Curriculum Vitae}

\section{CONTACT INFORMATION}

Office

$\begin{array}{ll}\text { Address: } & \begin{array}{l}\text { Department of Psychology } \\ \text { Syracuse University } \\ \end{array} \\ & \text { 430 Huntington Hall } \\ & \text { Syracuse, NY 13244-2340 } \\ \text { Phone: } & \text { (315) 443-9917 } \\ \text { E-mail: } & \text { JPMcFall@syr.edu }\end{array}$

Home

Address: $\quad 156$ Washington ST

Phone: (716) 353-1784

E-mail: Joseph.McFall@gmail.com

\section{EDUCATION}

$2008-2010$

Ph.D., Life-Span Developmental Psychology, May 2010 (to be conferred) West Virginia University, Morgantown, WV

Dissertation: Effectiveness of strategies for solving everyday problems during early and later adulthood: A reexamination of the Everyday Problem Solving Inventory

Chair: JoNell Strough, Ph.D.

2005 - 2007 M.S., Psychology, December 2007

West Virginia University, Morgantown, WV

Thesis: $\quad$ Effectiveness of older and younger adults' strategies for solving interpersonal and individual everyday problems

Chair: JoNell Strough, Ph.D.

2001 - 2005 B.A., Summa Cum Laude, Sociology/Anthropology, Psychology, May 2005 State University of New York at Fredonia, Fredonia, NY

\section{ACADEMIC HONORS}

2008

2005

2005

2005

2004
The Honor Society of Phi Kappa Phi

Sigma Phi Omega National Academic Honor and Professional Society in Gerontology

Alpha Kappa Delta International Sociology Honor Society

Golden Key International Honour Society

Psi Chi National Honor Society in Psychology 
- Everyday problem solving across the life span

- Judgment and decision making across the life span

- Mechanisms underlying successful aging

- Risk prevention/intervention across the life span

\section{SKILLS}

- Univariate and multivariate statistics (SPSS, AMOS)

- Programming (Visual Basic)

- Dyadic data analysis

- Online teaching \& course management (Blackboard Learning Systems)

- Online research management software (Sona)

\section{PEER-REVIEWED PUBLICATIONS}

Strough, J., McFall, J. P., \& Schuller, K. L. (2010). Endorsement of interpersonal strategies for dealing with hypothetical everyday arthritis problems as a function of marital status, gender, and problem severity. The International Journal of Aging and Human Development, 70, 39-59.

Spielmans, G. I., Gatlin, E. T., \& McFall, J. P. (2009). The efficacy of evidence-based psychotherapies versus usual care for youth: Controlling confounds in a meta-reanalysis. Psychotherapy Research. Advance online publication. doi:10.1080/105033D0903311293.

Strough, J., McFall, J. P., Flinn, J. A., \& Schuller, K. L. (2008). Collaborative everyday problem solving among same-gender friends in early and later adulthood. Psychology and Aging, 23, 517-530.

Strough, J., Mehta, C. M., McFall, J. P., \& Schuller, K. L. (2008). Do older and younger adults make different decisions about sunk costs? Psychological Science, 19, 650-652.

Spielmans, G. I., Pasek, L. F., McFall, J. P. (2007). What are the active ingredients in cognitive and behavioral psychotherapy for anxious and depressed children? A meta-analytic review. Clinical Psychology Review, 27, 642-654.

Spielmans, G. I. \& McFall, J. P. (2006). A comparative meta-analysis of clinical global impressions change in antidepressant trials. Journal of Nervous and Mental Disease, 194, 845-852.

\section{MANUSCRIPTS UNDER REVIEW}

Strough, J., Schlosnagle, L., McFall, J. P., Keener, E. J., \& DiDonato, L. M. No time to lose: Limiting future time perspective decreases the sunk-cost fallacy.

\section{MANUSCRIPTS IN PREPARATION}

McFall, J. P. \& Strough, J. Effectiveness for solving everyday problems during early and later adulthood: Gains or losses? 
McFall, J. P. \& Strough, J. Collaboration: Beneficial or detrimental for effective problem solving in early and later adulthood?

McFall, J. P. \& Strough, J. Individual differences in everyday problem-solving styles.

\section{INSTRUCTIONAL MATERIALS}

Strough, J. \& McFall, J. P. (2008). Course guide for social psychology. Littleton, MA: Tapestry Press.

\section{PRESENTATIONS}

McFall, J. P., Keener, E. J., Strough, J., \& Schlosnagle, L. (2009, November). Interpersonal processes between older adult friends: An actor-partner model. Poster submitted to the $62^{\text {nd }}$ Annual Scientific Meeting of the Gerontological Society of America, Atlanta, GA.

Strough, J., DiDonato, L. M., Schlosnagle, L., McFall, J. P., \& Keener, E. J. (2009, November). Justifying decisions about sunk costs: Do older and younger adults report different goals? Poster session submitted to the $62^{\text {nd }}$ Annual Scientific Meeting of the Gerontological Society of America, Atlanta, GA.

Strough, J., DiDonato, L. M., Schlosnagle, L., Keener, E. J., McFall, J. P., Mehta, C. M. (2009, May). The sunk-cost fallacy is associated with older and younger adults' future time perspective. Poster session presented at the $21^{\text {st }}$ Annual Conference of the Association for Psychological Science, San Francisco, CA.

McFall, J. P. \& Strough, J. (2008, November). Age differences in effective everyday problem solving. Poster session to be presented at the $61^{\text {st }}$ Annual Scientific Meeting of the Gerontological Society of America, National Harbor, MD.

McFall, J. P. \& Strough, J. (2008, November). Everyday problem-solving performance of collaborating pairs: A look at older and younger adults' strategy effectiveness. In J. P. McFall \& J. Strough (Chairs), Aging in a Social Context: Implications for Everyday Cognitive Performance. Symposium to be conducted at the $61^{\text {st }}$ Annual Scientific Meeting of the Gerontological Society of America, National Harbor, MD.

Schlosnagle, L., McFall, J. P., \& Strough, J. (2008, November). Perceptions of custodial grandparents: Problem interpretations predict expectations about grandparent adjustment and caregiving. In D. K. Tomczewski \& J. Patrick (Chairs), Attitudes toward custodial grandparenting. Symposium to be conducted at the $61^{\text {st }}$ Annual Scientific Meeting of the Gerontological Society of America, National Harbor, MD.

Strough, J., McFall, J. P., Flinn, J. A., \& Schuller, K. L. (2008, November). Collaboration with a familiar partner and younger and older adults' strategies for solving everyday problems. Poster session to be presented at the $61^{\text {st }}$ Annual Scientific Meeting of the Gerontological Society of America, National Harbor, MD.

Spielmans, G. I., Gatlin, E. T., \& McFall, J. P. (2008, August). Evidence-based treatment versus usual care: A meta-re-analysis. Poster session presented at the 2008 American Psychological Association Convention, Boston, MA.

McFall, J. P. \& Strough, J. (2008, March). Age differences in effective everyday problem solving. Poster session presented at the Eberly College of Arts and Sciences' Research Horizons Day, Morgantown, WV. 
McFall, J. P. \& Strough, J., \& Mehta, C. M. (2007, November).Sunk cost decision making: Who has the advantage and why? Poster session presented at the $60^{\text {th }}$ Annual Scientific Meeting of the Gerontological Society of America, San Francisco, CA.

Strough, J., McFall, J. P., \& Schuller, K. L. (2007, November). Understanding everyday problemsolving performance in nominal and interacting pairs. In A. Rauers \& A. Kleinspehn (Chairs), A lifespan perspective on dyadic interactions. Symposium conducted at the $60^{\text {th }}$ Annual Scientific Meeting of the Gerontological Society of America, San Francisco, CA.

Strough, J., McFall, J. P., \& Flinn, J. A. (2006, November). Friends' goals for collaborative problem solving in early and later adulthood. In C. Hoppmann \& F. Blanchard-Fields (Chairs), On the role of goals for solving everyday problems and coping across the lifespan. Symposium conducted at the 59th Annual Scientific Meeting of the Gerontological Society of America, Dallas, TX.

Strough, J., Schuller, K. L., Flinn, J. A., Mehta, C. M., \& McFall, J. P. (2006, November). Collaborating to make decisions: Are two heads better than one? In J. Strough \& C. Berg (Chairs), Social cognition: Are two heads better than one? Symposium conducted at the 59th Annual Scientific Meeting of the Gerontological Society of America, Dallas, TX.

Spielmans, G. I., Pasek, L. F., \& McFall, J. P. (2006, August). What are the Active Ingredients in Cognitive and Behavioral Psychotherapy for Anxious and Depressed Children? A MetaAnalytic Review. Poster session presented at the 2006 American Psychological Association Convention, New Orleans, LA.

McFall, J. P. \& Strough, J. (2006, May). Collaborators' judgment and decision-making errors on individual and interpersonal problems. Poster session presented at the $18^{\text {th }}$ Annual Conference of the Association for Psychological Science, New York, NY.

McFall, J. P. \& Strough, J. (2006, April). Collaborators' judgment and decision-making errors on individual and interpersonal problems. Poster session presented at the Eberly College of Arts and Sciences' Research Horizons Day, Morgantown, WV.

McFall, J. P. \& Spielmans, G. I. (2005, October). Comparative meta-analysis of clinical global impressions scale change in antidepressant trials. Poster session presented at the Eberly College of Arts and Sciences' Research Horizons Day, Morgantown, WV.

Spielmans, G. I. \& McFall, J. P. (2005, August). Comparative meta-analysis of clinical global impressions scale change in antidepressant trials. Poster session presented at the 2005 American Psychological Association Convention, Washington, DC.

\section{PROFESSIONAL EXPERIENCE}

$\begin{array}{ll}2009-2010 & \begin{array}{l}\text { Visiting Assistant Professor, Department of Psychology } \\ \text { Syracuse University, Syracuse, NY }\end{array} \\ 2007-2009 & \begin{array}{l}\text { Graduate Teaching Assistant, Department of Psychology } \\ \text { West Virginia University, Morgantown, WV }\end{array} \\ 2007-2008 & \begin{array}{l}\text { Program Evaluation Practicum } \\ \text { Osher Lifelong Learning Institute, Morgantown, WV }\end{array} \\ 2006-2007 & \begin{array}{l}\text { Graduate Research Assistant, Department of Psychology } \\ \text { West Virginia University, Morgantown, WV }\end{array} \\ 2005-2006 & \text { Graduate Teaching Assistant, Department of Psychology }\end{array}$


West Virginia University, Morgantown, WV

PROFESSIONAL AWARDS

2008

2007

2007

2006

2005-2008
William E. Vehse Graduate Student Travel Award (\$500)

Association for Psychological Science Service Award

WVU Psychology Department Alumni Fund Thesis Research Grant (\$515)

Association for Psychological Science Service Award

WVU Eberly College Doctoral Stipend Enhancement Award $(\$ 2,000)$

\section{PROFESSIONAL AFFILIATIONS}

2008 - present American Evaluation Association

2005 - present American Psychological Association

2005 - present Association for Psychological Science

2005 - present Gerontological Society of America

\section{STUDENT AFFILIATIONS}

2005 - present Association for Gerontology in Higher Education

2005 - present American Psychological Association of Graduate Students

2005 - present Association for Psychological Science Student Caucus

\section{STUDENT AND PROFESSIONAL ACTIVITIES}

2006 - $2008 \quad$ Student Research Competition Reviewer Association for Psychological Science Student Caucus

2006 - $2008 \quad$ Student Grant Competition Reviewer

Association for Psychological Science Student Caucus

$2006-2008 \quad$ Campus Representative

Association for Psychological Science Student Caucus

$2006-2007 \quad$ Institutional Review Board Task Force Member

WVU Department of Psychology

$2006-2007 \quad$ Assisted Advisor with Ad Hoc Reviewing Journal of Gerontology: Psychological Sciences

2005 - $2008 \quad$ Officer (Chair: 2005 - 2006, 2007 - 2008)

West Virginia University Gerontological Society of America Student Chapter

\section{COURSES TAUGHT}

Summer 2010

Child Psychology, 1 section of 45 students (scheduled course)

Spring 2010

Graduate course: Life-Span Developmental Psychology 
Child Psychology, 2 sections of 100 students

Fall 2009

Summer 2009

Spring 2009

Fall 2008

Summer 2008

Spring 2008

Fall 2007

Spring 2007

Spring 2006

Fall 2005
Foundations of Human Behavior, 1 section of 45 students Child Psychology, 1 section of 120 students

Introduction to Psychology, 1 section of 15 students

Introduction to Social Psychology, 1 section of 60 students In-class course

Professional Field Experience in Psychology, 1 section of 40 students Online course

Introduction to Social Psychology, 1 section of 60 students In-class course

Professional Field Experience in Psychology, 1 section of 40 students Online course

Introduction to Psychology, 1 section of 45 students

Introduction to Social Psychology, 2 sections of 60 students

Introduction to Social Psychology, 2 sections of 60 students

Introduction to Social Psychology, 2 sections of 60 students

Introduction to Psychology, 1 section of 120 students

Introduction to Psychology, 1 section of 120 students

\section{MENTORING EXPERIENCE}

Spring 2010

Fall 2009

Spring 2009

Fall 2008

Summer 2008

Spring 2008

Fall 2007

Spring 2007

Fall 2006

Spring 2006

Fall 2005
Pre-capstone research supervision 2 undergraduate research assistants

Pre-capstone research supervision 4 undergraduate research assistants

Capstone research project supervision Intensive writing project supervision 5 undergraduate research assistants

Intensive writing project supervision 4 undergraduate research assistants

2 undergraduate research assistants

2 undergraduate research assistants

1 undergraduate research assistant

2 undergraduate research assistants

4 undergraduate research assistants

Capstone research project supervision 3 undergraduate research assistants 4 undergraduate research assistants 


\section{REFERENCES}

JoNell Strough

Professor and Chair, Life-Span Developmental Program

Department of Psychology, West Virginia University

Morgantown, WV 26506-6040

Phone: 304-293-2001 ext. 31648

Julie Hicks Patrick

Associate Professor and Director of Undergraduate Studies

Department of Psychology, West Virginia University

Morgantown, WV 26506-6040

Phone: 304-293-2001 ext. 31680

Katherine Karraker

Professor of Psychology and Associate Dean of Student Affairs

West Virginia University

Morgantown, WV 26506-6040

Phone: 304-293-2001 ext. 31625

Glen Spielmans

Associate Professor

Department of Psychology, Metropolitan State University

1450 Energy Park Drive

Saint Paul, MN 55108

Phone: 651-999-5826 